The Mechanization of Cladding: The Reliance Building and Narratives of Modern Architecture

Author(s): Joanna Merwood

Source: Grey Room, No. 4 (Summer, 2001), pp. 52-69

Published by: The MIT Press

Stable URL: https://www.jstor.org/stable/1262558

Accessed: 11-12-2018 22:36 UTC

JSTOR is a not-for-profit service that helps scholars, researchers, and students discover, use, and build upon a wide range of content in a trusted digital archive. We use information technology and tools to increase productivity and facilitate new forms of scholarship. For more information about JSTOR, please contact support@jstor.org.

Your use of the JSTOR archive indicates your acceptance of the Terms \& Conditions of Use, available at https://about.jstor.org/terms 


\section{The Mechanization of Cladding: The Reliance Building and Narratives of Modern Architecture}

\section{JOANNA MERWOOD}

In a short article describing Adolf Loos's debt to Gottfried Semper's theory of cladding, or Bekleidung, Joseph Rykwert makes a momentary digression from his argument. Referring to Frank Lloyd Wright's concrete "textile" blocks, Rykwert uses D. H. Burnham and Co.'s 1895 Reliance Building as a bridge between Semper and Wright. Wright's blocks may be seen in relation to the Semperian theory of the origin of cladding in textiles, he claims, if we remember that Wright had plenty of opportunity to learn of Semper's theory during his early years in Chicago. After all, Rykwert goes on to say, Semper's first English translator was Chicago architect John Wellborn Root, whom he describes as "a partner of Dan Burnham, whose Reliance Building has some claim to have the first curtain-walls." Rykwert's reference to the Reliance Building in this way is somewhat perplexing. The Reliance is nowhere described as the indisputably original curtain-wall building. It was not even the first to employ an entirely terra-cotta-tile façade. (Burnham and Root's Rand McNally Building preceded it by five years.) Rykwert's use of the Reliance Building to make this rhetorical jump makes sense only if we understand that he is drawing on a common reading of the Reliance as the representative example of a "protomodern" building in its use of steel-framed construction and in its blatantly nonstructural employment of terra-cotta. His ability to call up these allusions in a single brief reference assumes that his readers will understand the building in this metonymic way.

In architectural histories, the story of the terra-cotta-clad, fourteenstory Reliance, designed by Charles Atwood for D. H. Burnham and Co. from 1891 to 1895 , is told within a larger and familiar narrative. According to this account, the building represents a symbolic watershed from one movement in American architecture to another: from historicism to experiments with the "potentialities" of new architectural technologies. ${ }^{2}$ As such, it is repeatedly described as "prophetic" of the development of American modernism. Articles on the building's 
D.H. Burnham and Co.

Reliance Building, 1891-95, c. 1900.

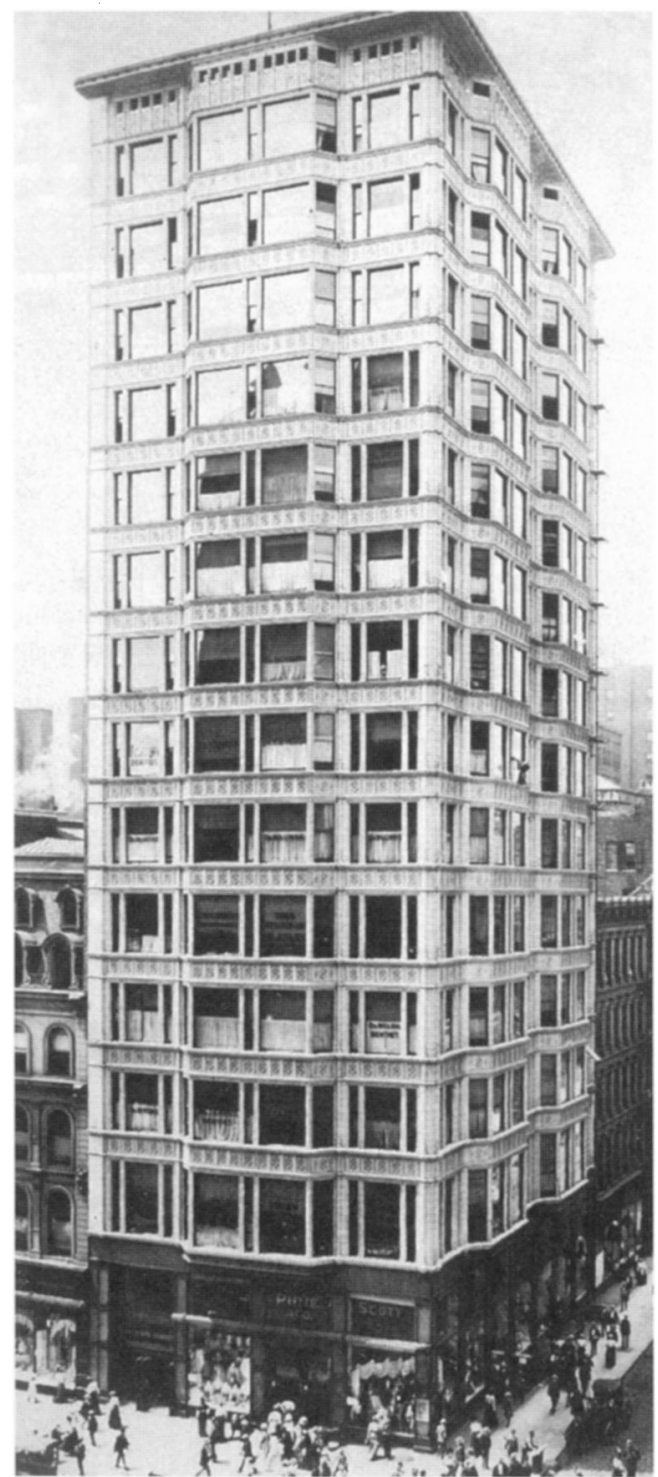
All use subject to https://about.jstor.org/terms 
recent restoration have unquestioningly reiterated these claims. In all these stories, the same few black and white photographs of the building, obscured by shadows, scratches, clouds, and dust, are reproduced over and over. The details of the window mullions, the terra-cotta tile, the people walking in the street below are blurred, muddied, and thrown into shadow. The sky, the reflections in the windows, the painted advertising signs, the curtains and shades are hazy, sometimes even obliterated through graphic editing.

After repeated calls for its restoration beginning in the 1970s, work was finally begun on the Reliance in 1998, and it has been renovated to accommodate the new Hotel Burnham. Recent photographs published in architectural journals restore its crisp and bright image. ${ }^{3}$ The layers of dirt have been removed from the old and dingy façade to reveal a finely molded, rich off-white terra-cotta tile. However, the content and composition of the image remain the same; a three-quarter view showing the two principal street façades, taken with a wide-angle lens from the upper stories of an adjacent building. The Reliance continues to be represented by these two walls. ${ }^{4}$ In late-nineteenth-century criticism and in modernist architectural histories, the nature of these two surfaces has been endlessly discussed. Of particular interest has been their apparent materiality or immateriality, weight or weightlessness, transparency or opacity, color or colorlessness. The questions asked of these walls are questions of the media of modern architecture, worked through via its photographic image.

In assessing the place of the Reliance in the modernist canon, historian Carl Condit wrote, "If any work of structural art in the nineteenth

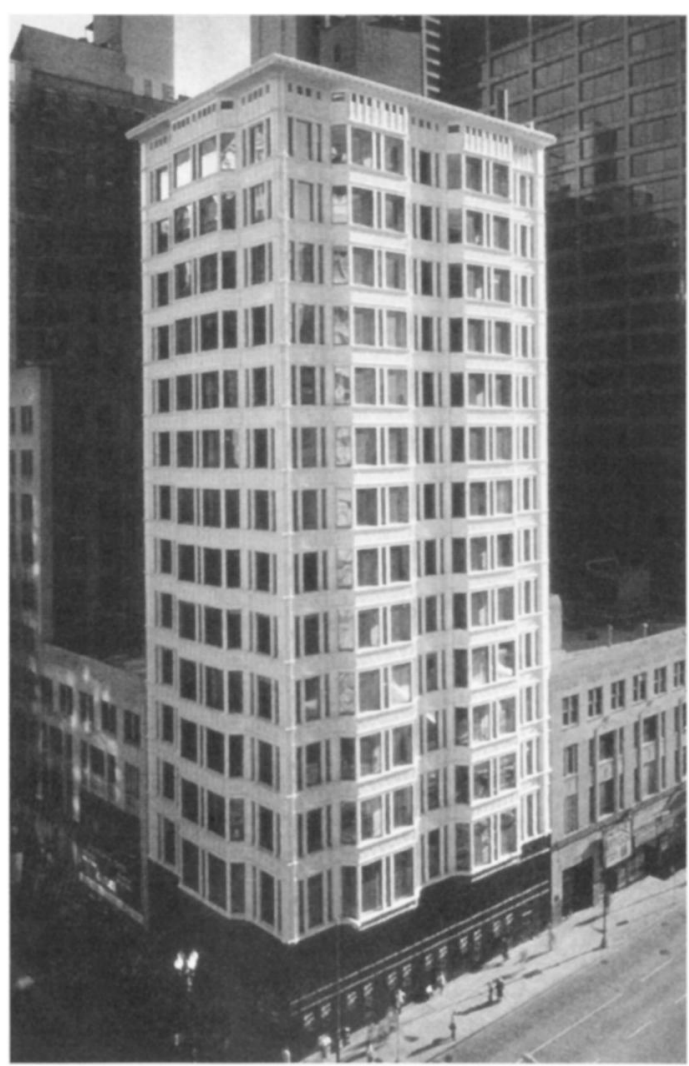
century anticipated the future, it is this one.... Atwood succeeded in developing almost to its ultimate refinement the modern dematerialized curtain wall, and this made the building a direct forerunner of the work of Le Corbusier and Mies in the twenties."5 In his description of what he saw as the Reliance's forward-looking (because dematerialized) wall, Condit echoed claims first made by Sigfried Giedion in Space, Time and Architecture in 1941. For Giedion, the building was "an architectonic anticipation of the future." Claiming the Reliance as a symbol of the "spirit of the Chicago School," he praised the way the large sheets of plate glass and terra-cotta tile appeared almost to be in the same plane, forming for the first time a wall as undulating veil, rather than a sculpted mass. ${ }^{6}$

Reliance Building

after 1999 restoration. 
While the modernist reading of the tiled building as a glass building has dominated discussion of the Reliance ever since, at the time of its construction its reception was subsumed within a larger argument about the use of terra-cotta as an appropriate material for architecture. The building's contemporary critics were less concerned with its windows than with its other curious cladding material. Commenting on the novelty of a façade made entirely of off-white terra-cotta, the critic for the American Architect and Building News wrote, "The effect is not so startling as it might seem, but, most assuredly, treated as the material is in this mammoth sky-scraper, it is possessed of few charms." Engineering Magazine of London chose to illustrate the building because of its unusual construction method, while claiming that "in its external appearance, it is not admirable." ${ }^{8}$ Engineers and more technically minded architects were interested in the building because of its technological innovation, and nonarchitects were fascinated by the novel slenderness of its ascending profile. Architectural critics themselves were at best ambivalent. They described the design as the embodiment of the "money-getting spirit of the age."9 This view of the skyscraper as an uncritical material representation of an economic system, as the device through which Chicago's new ruling class of corporate businessmen displayed their wealth and power, was later to be repeated by Manfredo Tafuri and Francesco Dal Co in their history of modern architecture. These critics described buildings like the Reliance as laissez-faire capitalism made manifest, its physical requirements unquestioningly answered, and their message directly broadcast. Holabird and Roche, designers of the Tacoma Building, "reduced the sky-scraper as a type to its primary vocation: to soar above the city as pure sign," wrote Tafuri and Dal Co. ${ }^{10}$

In such a reading, the orderly structural steel skeleton represented the brutal reality of the new conditions of production, whereas the pliable and delicate terra-cotta cladding was molded and shaped into an attractive and ultimately banal mask, disguising the interior machinations. The pliability and apparent flimsiness of this cladding also disturbed its contemporary critics. In 1891, the venerable Chicago architect William Le Baron Jenney wrote an article in the Inland Architect and

\footnotetext{
Top: Reliance Building as published in Sigfried Giedion's Space Time and Architecture (1941).

Bottom: D.H. Burnham and Co. Perspective and plans of the Reliance Building as published in Engineering Magazine, London (October 1894-March 1895).
}

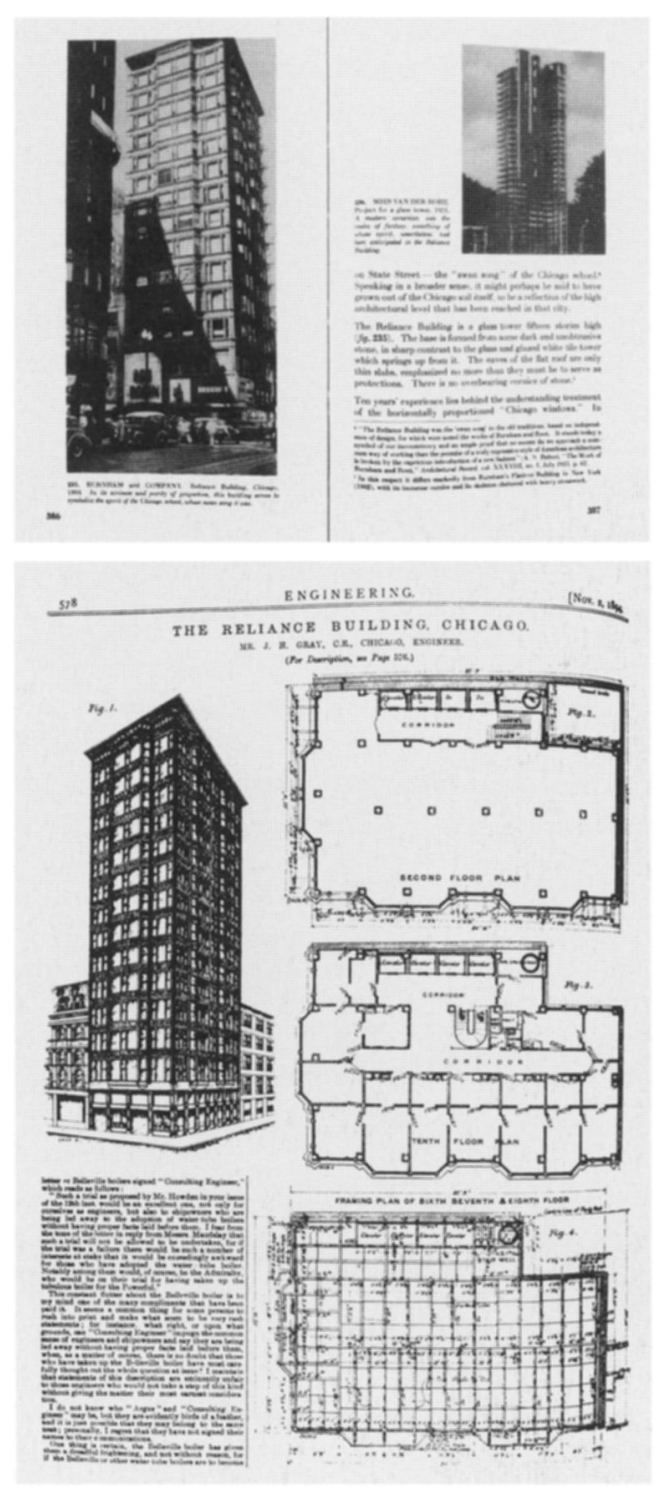


News Record defining "the Chicago construction" and describing the design process of the Home Insurance Building of 1883. Chiefly a technical essay comparing the construction of the new "tall buildings" to "the construction of a railway bridge of the first order," the piece emphasizes the precision with which calculations must be made. "There must be sufficient material and no more," wrote Jenney, "for it is essential, not only from economy but also to reduce the weights on the foundations, that the construction should be as light as possible consistent with stability." His last paragraph is clearly addressed to those who doubted this delicacy. "Tall buildings, constructed as described," he concludes, "are very substantial, and even earthquake-proof." ${ }_{11}$

However, the new structural system led not only to fears for the stability of tall buildings, but also to fears for the future of architecture. In an 1896 survey of the buildings of Burnham's company, critic Montgomery Schuyler gave his opinion of the new Chicago construction. "In the buildings in which the construction is really followed," he wrote, "and
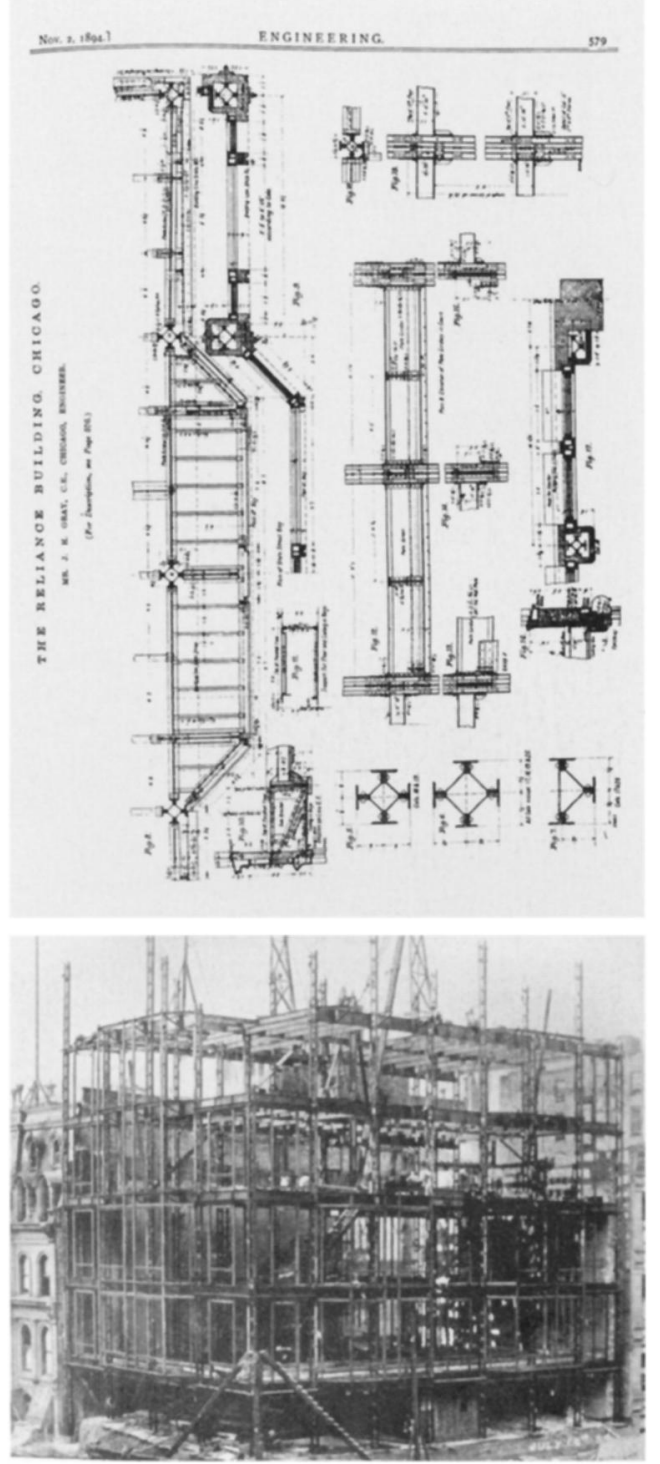

the wall is omitted, even at the base, the highest success that has thus far been attained amounts rather to a statement of the problem than to a solution of it." 12 In this way, Schuyler implied that a system of lightweight cladding over a skeleton frame does not constitute a wall in any truly architectural sense. Indeed, a close look seems to support his claim that the façade of the Reliance does not even attempt to simulate four load-bearing walls. Only two of the four sides are clad in terracotta. The other two are plain brick, with very few openings. The edges where the terra-cotta meets the brick are designed in imitation of a frame-like pilaster. The same pilaster is repeated where the two terra-cotta walls meet, but in this case the pilaster is folded around the corner, appearing only half as wide as its partner on the other edge. In this way, the terra-cotta cladding seems to literally wrap itself around its inner structure, with no pretense that it is supporting weight at its leading corner. ${ }^{13}$

This architectural illusion did not go unnoticed. For Schuyler, unlike Giedion, the problem with the building wasn't that it was too material, it was that it wasn't material enough. He questioned whether it could properly be called architecture at all.

Top: D.H. Burnham and Co.

Details of the Reliance Building as published in Engineering Magazine, London (October 1894-March 1895).

Bottom: Reliance Building under construction, July $16^{\text {th }} 1894$. 
[The Reliance is] one of the most typical ... of the essays in which the skeleton is undraped, and no attempt is made to "do something" with it. . . . Its most obvious peculiarity is that the protecting envelope is of glazed white terra cotta. Practically this is a very eligible material in the atmosphere of Chicago, but the employment of it throughout seems almost like the frank abandonment of architecture.... The covering is confessedly a covering and does not in the least simulate a structure nor dissemble the real structure ... if this is the most and the best that can be done with the sky-scraper, the sky-scraper is architecturally intractable. ${ }^{14}$

The architecturally intractable is that which is uncontrollable, ungovernable, and willful. For Schuyler, the Reliance refused to follow the rules that dictated that it might simulate another structure (as Burnham and Root's earlier Rookery Building had simulated the Romanesque) or dissemble the real structure, as an industrial building or railway shed might.

As we have seen, both late-nineteenth-century critics of the building and the modernist historians who selected the Reliance as prototypical of modern architecture considered its terra-cotta and glass cladding entirely supplementary to its structure. Both denied its material presence as sufficiently "architectural.” For Schuyler, not only did the wall fail in its representational role, but materially it failed to form a sufficient barrier between inside and outside. In Giedion's mind, however, the wall was worthy of note because it was suggestive of a future permeability not yet achieved.

Rykwert's reference to the origin of the curtain wall in an article on Semper comes as part of a revisionist movement within architectural history, a movement that reexamines nineteenth-century historicism, in particular the role of ornament. This movement has led to new claims for the relationship between structure and cladding in the early business blocks of Chicago. Much work has been done to suggest that Schuyler's interpretation of the building's façade as "confessedly a covering" may in fact have been the intent of the architects. In support of this, Robert Bruegmann offers the memoir of an employee of Holabird and Roche, suggesting that the use of a skeleton construction for the Tacoma Building was first proposed by Sanford Loring, president of

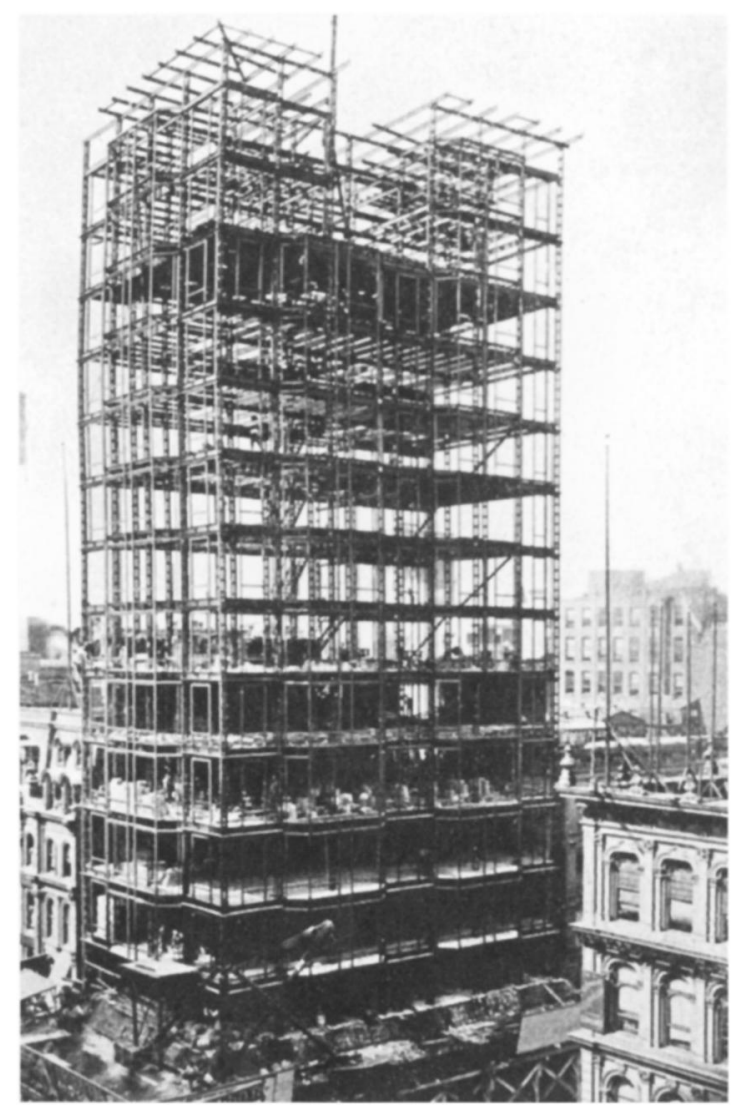

Merwood | The Mechanization of Cladding 
the Northwestern Terra Cotta Company, in order that his product might be used to clad the building. ${ }^{15}$ In his 1956 essay, "Chicago Frame," Colin Rowe tells a slightly different version of this story, using Louis Sullivan to support him. Rowe claims that architects were sold the idea of steel-framed buildings by the sales managers of local steel mills. He uses this to argue that late-nineteenth-century architects did not use new materials in the service of architectural experimentation, but economic necessity. ${ }^{16}$ In Rowe's modernist reading, the generating material is structural steel, not terra-cotta. However, Bruegmann's story implies that the skeletal structural system may have been employed in the service of the terra-cotta cladding, rather than vice versa. In other words, the narrative of Giedion, Rowe, and other modernist historians of the accepted relationship between cladding and structure is exactly inverted, reversing a fundamental and defining modernist dictate. It is in the context of this interpretation that we can understand how Rykwert might use the Reliance as the link between Semper and Loos's theories of cladding, the Chicago curtain wall, and Frank Lloyd Wright.

Semper's theory states that the wall retains the trace of its origin in woven textiles through centuries of replication in different materials, that the ghost of a long tradition of handcraft may be seen in its ornament and manufacture. It is the nature of this reproduction, or replication, that disturbed contemporary critics of the Reliance. They objected to the serial, repetitive nature of its walls and called for differentiation in the design of the façade so that an architectural identity might be created. An anonymous critic for the American Architect and Building

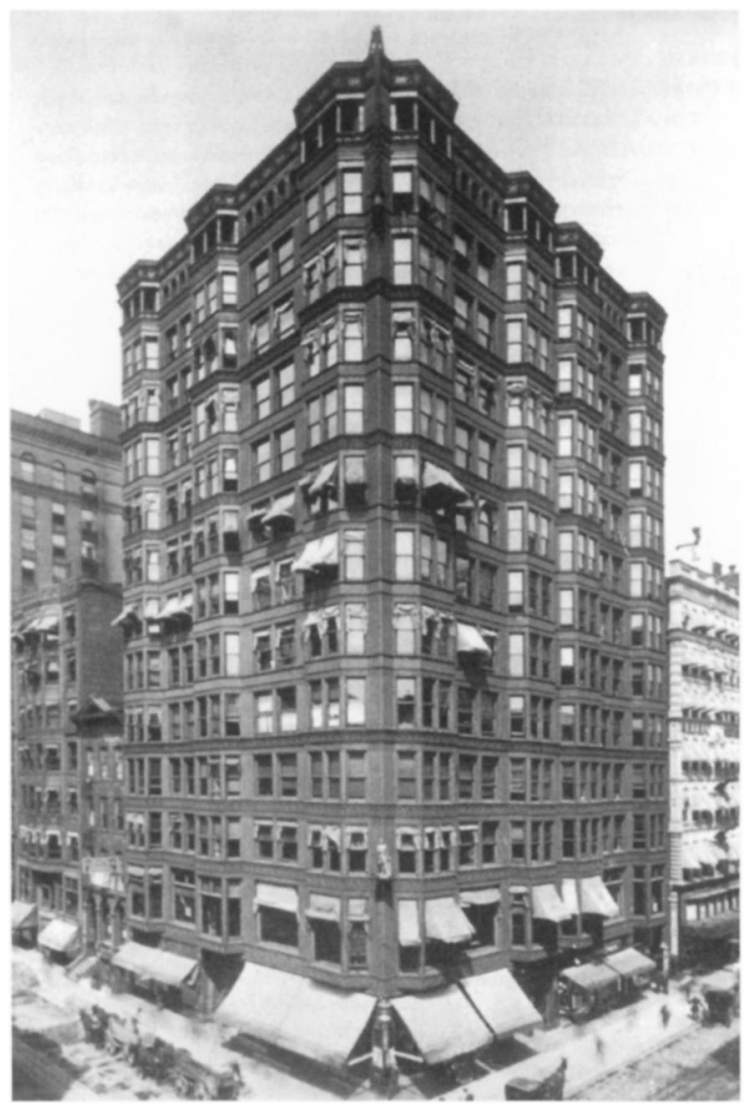

News wrote of the Reliance, "There is no grouping of windows attempted, no relief from the rows and rows of stories, one placed over another."17

This disdain for undisguised seriality appears to relate only to terra-cotta, not to brick, a material that might be thought open to the same criticism. For example, Schuyler noted the homogeneity of the façade of Burnham and Root's Monadnock (18891892), but he praised this austere masonry building as a demonstration of the commercial building as "the thing in itself." For him, it was sufficient that the Monadnock be "impressive" rather than "expressive." 18 This heavy building need not express a mimetic identity, rather it directly impressed itself upon the viewer as pure mass. This archi-

Holabird and Roche.

Tacoma Building, Chicago, 1888-89. 
tectural impression must have something to do with the weight of masonry, since the lightweight cladding of the Reliance apparently could not legitimately be perceived in this way. The Reliance could not be perceived empathetically, only "seen through."

The Reliance was transparent to Schuyler, but not in the way Giedion understood it. It was transparent because it was without signification. It did not "appear" in any meaningful way and might be considered invisible as architecture. It was a blank, a purely technical construction, built for commercial rather than artistic purposes, representing only the economies of construction, circulation, and occupation, but inexplicably sheathed in this peculiar covering.

The engineer George M. R. Twose was perhaps more perceptive than contemporary critics in his recognition that terra-cotta was in fact a material wholly in keeping with the architecture of the time. In an 1894 article entitled "The Use of Terra-Cotta in Modern Buildings," Twose argued that although it was initially used in this period as a replica of stone, terra-cotta ought now to be thought of as a material in its own right. ${ }^{19}$ It was clear that new guidelines were needed for its use as cladding, since those that John Ruskin had set down for natural materials, in relation to truth and authenticity, no longer applied. Twose was one of the first to realize that this material represented the "mechanization" of cladding, since new colors, shapes, and patterns could be created and almost infinitely reproduced, and the material could be quickly and cheaply manufactured and erected. The design of the tiles used on the Reliance, imprinted with a flat, repetitive geometric ornament that is clearly stamped and not carved, fulfilled Twose's demands that full advantage be taken of the plasticity of the new material. However, even Twose complained that terra-cotta was "beginning to suffer from too high a pitch of material perfection." 20 That is, that the color and texture of terra-cotta were becoming too precisely manufactured, and this mechanized perfection was becoming apparent to the eye.

The initial confusion over how to treat the Reliance, and other buildings like it, continued into the twentieth century. As late as 1939, the canonical skyscrapers of this era were still being described by the architect Thomas Tallmadge as inferior to the masonry high buildings that preceded them. "The skyscrapers that came after the

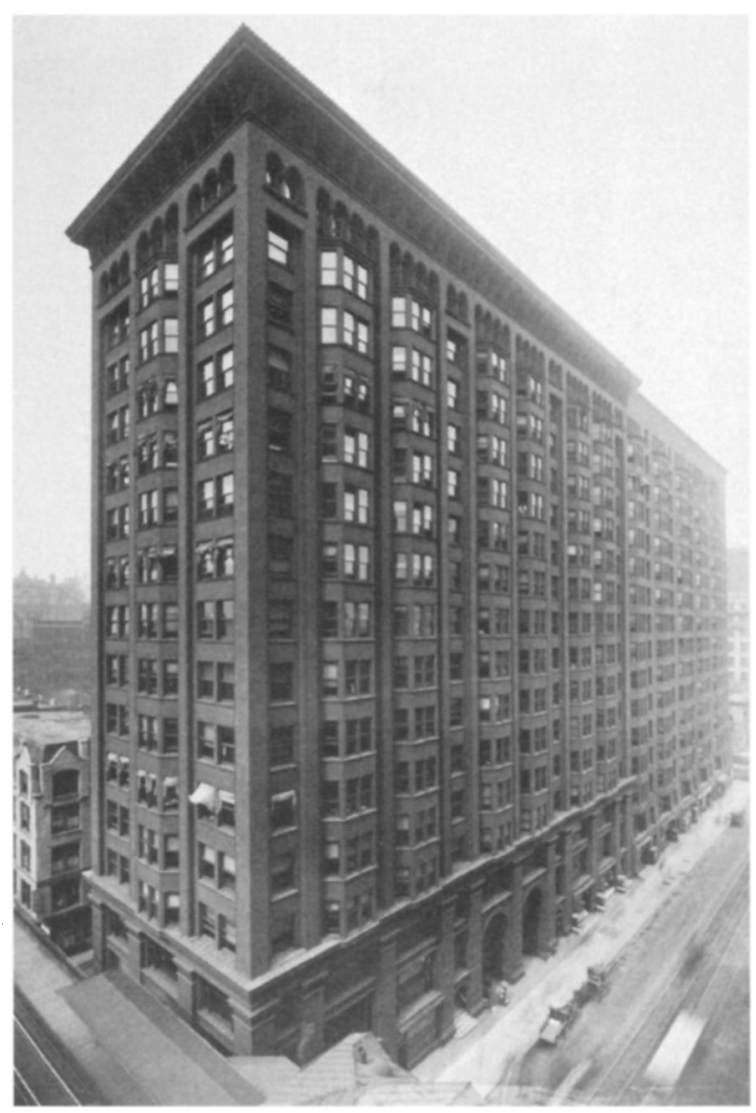


World's Fair in 1893 and which attempted almost without exception to apply Classical architecture to the steel skeleton, were far inferior aesthetically to the simple and honest Elevator buildings and the early sky-scrapers," he wrote. ${ }^{21}$ The façade of the Reliance was not to be treated favorably until Giedion co-opted the building as the beginning of a "new tradition" in Space, Time and Architecture. Finally, these strange buildings were "like" something else. "It is as a densely faceted tower of glass that the Reliance comes by its visual force," wrote William H. Jordy in $1972 .{ }^{22}$ This association was encouraged by a particular way of reading the photographic image. For Giedion, the building must be seen through half-closed eyes. In this way, its walls dissolved into a thin hazy film, and it might properly be compared to Mies van der Rohe's 1921 project for a glass skyscraper.

"The New Architecture throws open its walls like curtains to admit a plenitude of fresh air, daylight and sunshine,"23 wrote Walter Gropius, setting out the three essential foundations upon which the conception of modernist transparency was founded: the first, that the glass wall does not really exist as a physical barrier; the second, that freedom from confinement enables the inhabitant of architecture a closer connection with the earth itself and its elements; and the third, that the visibility allowed by transparent surfaces makes plain the unity of all buildings in the "single indivisible space" described by Giedion. It is in these terms that modernist historians could read the pale terra-cotta cladding of the Reliance as a stand-in for the glass curtain wall, a placeholder for a material that was not yet technically possible. To them, it

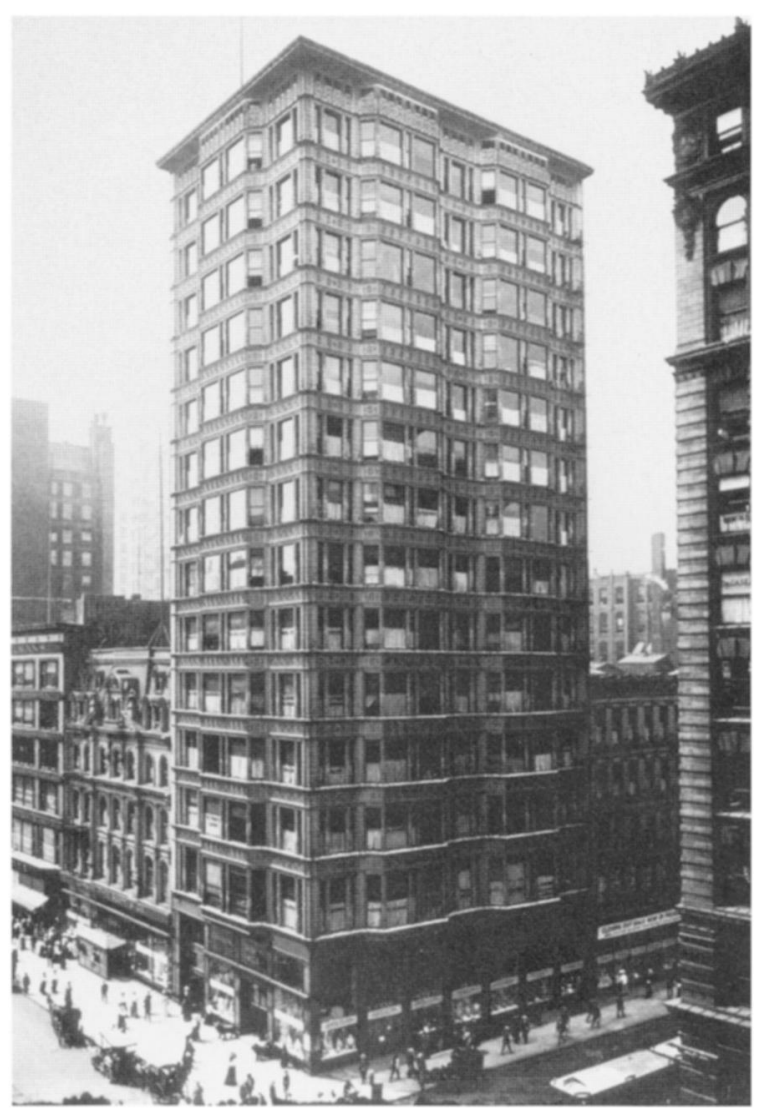
was conceptually transparent; the steel skeleton could be read beneath it. The use of tile was forgiven as an act of technological expediency.

In comparing two images of the Reliance, a 1904 postcard advertising the building and the one used by Giedion in Space, Time and Architecture, taken sometime in the 1940 s, we can see that the original muslin half-curtains shrouding every window have been replaced by blinds. In the second image, the blinds are mostly drawn, making the windows appear white, or blank. For Giedion, not only is the interior bounded only by notional walls, the building transcends the material world and exists in pure, clean atmosphere inside and out. The building's critics, however, were all too aware

D.H. Burnham and Co.

Reliance Building, c. 1904. 
that it did not occupy a void. For them, it was its ability to resist the alltoo-material climate around it that represented perhaps the Reliance's only favorable quality. In an 1895 article for Architectural Record, Charles Jenkins praised the use of the new material in this particular climate:

Should enameled terra cotta prove to be what is claimed for it, if it stands the test of Chicago's severe winters and changeable climate, there can be no possible doubt but that as a material for exterior construction it will be largely used in such cities as are afflicted with a smoky, sooty atmosphere. The idea of being able to wash your building and have it as fresh and clean as the day it was put up, must undoubtedly attract people to the use of this material. ${ }^{24}$

A guidebook to Chicago described the white glazed terra-cotta façade of Holabird and Roche's Champlain Building of 1884-1885 as "gleam[ing] out in quite a radiant fashion in the hazy vista of State Street, where Chicago's smoke creates an atmosphere that would delight an impressionistic artist." 25 This image of Chicago's climate as cloudy and indistinct, almost primeval, is used as a central metaphor in Henry Blake Fuller's 1893 novel of the business block, The Cliff-Dwellers. In an evocative early passage, Fuller strives to "naturalize" the environment of the modern city by describing the buildings as "cliffs" and the streets between them as "canyons." 26 His description of the streets of elevated office buildings as cliffs, as natural formations, was an attempt to humanize them by giving them an identifiable substance. ${ }^{27}$ The air itself is not "the mere combination of oxygen and nitrogen," but a vile soup. "Here the medium of sight, sound, light, and life becomes largely carbonaceous," he wrote, "and the remoter peaks of this mighty yet unprepossessing landscape loom up grandly, but vaguely, through swathing mists of coal-smoke." ${ }^{28}$ This naturalist literary metaphor had its architectural corollary in the office buildings built by Burnham and Root ten or fifteen years before the Reliance was conceived. Heavy masonry buildings like the Rookery employed a language of architecture as part Romanesque palazzo and part natural accretion. However, by the mid-1890s such Ruskinian metaphors had become unpopular. The "climate" in which the Reliance was built, perceived, and critiqued was undoubtedly that of Georg Simmel's Metropolis, the site and cause of multiple and overwhelming sensory stimuli, inextricably separated from the natural environment. The need for the business block to simulate the solidity of the local landscape was overcome.

Donald Hoffman has written that Atwood's design for the Reliance cannot be understood apart from his designs for the "White City" of the World's Columbian Exposition of 1893. Atwood used a common neoclassical language in all his work for Burnham. However, apart from at 
its ground-floor level, a high office building like the Reliance could not directly embody the phantasmagoria of commodity of the exposition hall or the department store. The work done inside was part of a much larger system of capital, with little trace of a physical product in evidence. The criticism of the material covering the building as mechanical and repetitive parallels that of the behavior induced in its occupants by the thoroughly new systems of organization (both mechanical and corporate) they were designed to house. Describing Burnham and Root's 1891 Mills Building in San Francisco, critic Henry Van Brunt wrote, "Thirteen stories of similar use and importance, typical of an industrial hive of democratic industry, find themselves expressed in an absolutely monotonous and unmitigated system of fenestration." ${ }^{29}$ This monotony dulled the senses and made difficult the direct perception of the physical world. In The Cliff-Dwellers, Fuller described the offices of a firm of salesmen in his fictitious skyscraper, the Clifton. Here the samples lay safely packed away in cases not to be seen, since "commerce is refined completely beyond the ken of the senses." 30 In this climate of commerce, the anxiety over the apparent ephemerality and insubstantiality of the walls of the Reliance may be said to reflect an anxiety over the nature of the work that went on inside them and the effect of that work on human life.

This sense of immateriality was compounded in architectural literature. In architectural histories, the Reliance's interior is rarely mentioned: the façade is seen as a curtain to the outside world, not an internal one. The nature of its interior is usually deemed unworthy of comment

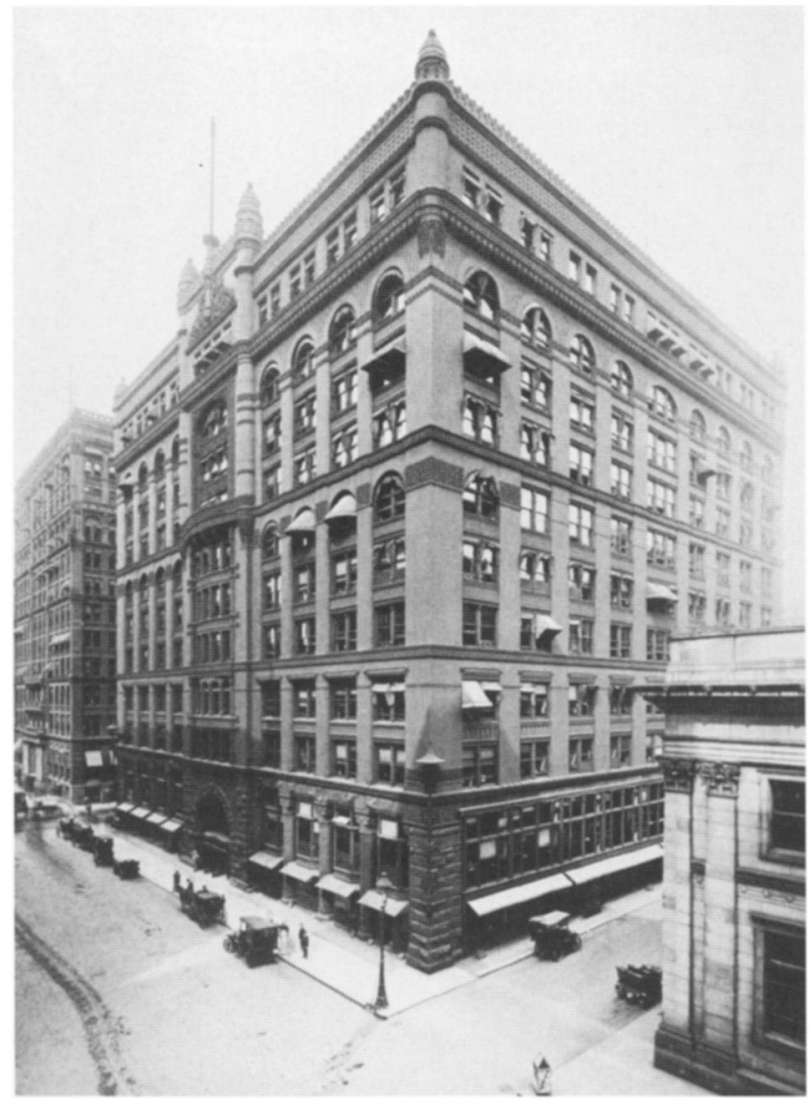

(this is so much so that when the first calls for the preservation of the building were made, only the exterior façade was thought worthy of restoration). Few images of the Reliance's interior were published, partly because of the difficulties of interior photography at the time of its construction. Descriptions of the interiors of late-nineteenth-century office buildings are typically nonvisual and occur in less academically specific writing, such as newspaper reports, guidebooks, and the literary genre of the "business novel," of which Fuller's novel is one example. Although plans are frequently published, the absence of ready photographs of the interior allowed the Reliance to continue to be read as pure

Burnham and Root.

The Rookery, Chicago, 1885-88. 
exterior in those narratives of architectural history that depended heavily on images. ${ }^{31}$ The interior effect created is one of absence, and the world outside is an artificial Potemkin city of façades. In this way, it is the street itself that becomes an interior. In Semper's terms, it is a space, screened or curtained by the façades of the high office buildings surrounding it, while the interior of those buildings remains an unknown void.

Fuller's description of the modern city of the American West is an elaborate metaphor of all that is savage and "anti-natural." He called the urban fabric of downtown Chicago a "city wilderness": an arid, dry landscape of rooftops and deep canyons. The idea of climate as inextricably bound together with the wider physical and social environment in which architecture is built is central to Semper's theory of origins. John Wellborn Root, Burnham's partner and the translator of Semper, struggled with the impact of the climate of the American West on its architecture. ${ }^{32}$ Like many writers, he thought of the adaptation of European architecture to the new land in terms of "acclimatization." ${ }^{33}$ The struggle in this adaptation was the struggle to survive in local conditions that were perceived as raw and uncivilized, as well as potentially psychically and physically damaging. Despite the abandonment of ideas of the acclimatization of architectural styles, the idea of "climate" in a larger sense did not disappear in descriptions of latenineteenth-century Chicago; rather, it was subsumed into the concept of "environment."

Questions of climate in relation to architecture appeared most directly in books and journals dedicated to public health. Works like the English scientist John Tyndall's Essays on the Floating Matter of the Air in Relation to Putrefaction and Infection (1882) alerted the public to the presence of "bacterial clouds" in the air. ${ }^{34}$ An article entitled "Chicago's Climate," published in the Inland Architect and Builder, is one of many that sought to bring the attention of architects to the dangers of bacterial infection and to the grossly polluted air that was daily being belched out by almost every building in the city. ${ }^{35}$ Like much architectural and popular writing of the time, these works reflected a Spencerian view of the organic interrelationship between all parts of a society, in which the functioning of one part affected the functioning of the whole. Numerous articles on the social scientist Herbert Spencer in Chicago's literary review, The Dial, attest to the interest his theories held for the inhabitants of that city. ${ }^{36}$ Depending on the assumption that all organizations, human or otherwise, functioned biologically, Spencer believed the essential "natural law" of society to be the principle of conservation of energy. "Whatever takes place in a society," he wrote, "results either from the undirected physical energies around, from these energies directed by man, or from the energies of men themselves." ${ }^{37}$ 
Spencer's claim that the environment contained only a finite amount of energy was reflected by the many books published at this time describing the symptoms and cause of "nervous exhaustion" and the enervating effects of the city life, as well as those popularizing various health cures (involving electricity, hydrotherapy, sea air, sea bathing, wilderness retreats, and the benefits of the California climate). ${ }^{38}$ Each had its basis in the belief that city living depleted energy that must be artificially replenished or restored by the removal of the subject to a healthier environment. In this way, the inhospitable climate formed by the forces of industry was conceived of as a palpably present and potentially dangerous mass of ungoverned energies whose course must be tamed and controlled and whose debilitating effects must be compensated for.

American architectural writing saw its first explicit use of the word "environment" (in the Spencerian sense) in the essays published in the early 1890 s by the young critic Barr Ferree. Although he was unsure as to whether architecture might be called a science, Ferree claimed that it could only benefit from some form of comparative analysis, since "architecture is shown to be a natural art evolved under natural conditions, not a mere succession of historical facts." He criticized what he called the "historical" and "descriptive" methods of architectural study, as they attended only to stylistic differences between the architecture of various countries and eras, rather than the reasons for their existence. Instead, he wrote, attention should be paid to "the substance of the art, its materials, the climate in which characteristic styles have developed, the national or governmental conditions under which they have flourished, the ethnographic relations of the people, the geological peculiarities of architectural districts, the distinctive social and mental qualities, the influence of the allied arts, of religion, of temperature, of use, of constructive ability, of methods and other causes which have operated in one way or another ... in the production of architecture in all times and in all ages." ${ }^{9}$ In "Architecture and Environment" (1890), Ferree had clearly defined the character of the modern environment. "Now, we have countless mechanical contrivances that have entered closely into our lives ....," he wrote, "and the problems of architecture take a different range. Steam and electricity have revolutionized society. ... Questions of public safety, correct sanitation, guards against fire, protection against burglary, safe means of rapid ingress and egress, have formed other conditions. The spread of manufactures, the making of artificial building materials, such as iron and glass, have given us new forces." 40 The world had changed so much, according to Ferree, that it constituted an entirely new environment, both as a place to live and as an object of study. 
It was, of course, Ruskin who most powerfully described this new climate of modernity, in highly romantic terms. In his 1884 lecture, "The Storm Cloud of the Nineteenth Century," he described to sinister effect the pattern of monstrous and unnatural storms, or "plaguewinds," he had observed throughout the last twenty years of his life. "By the plague-wind every breath of air you draw is polluted, half round the world"; he warned his audience. "In a London fog the air itself is pure, though you choose to mix up dirt with it, and choke yourself with your own nastiness.... I have come solely and simply to put before you a few facts, which you can't see by candlelight, or in railroad tunnels, but which are making themselves very distinctly felt as well as seen, that you may perhaps have to roof, if not wall, half London afresh before we are many years older." ${ }^{11}$ In other words, life in the modern city must be protected from these menacing forces by architectural means.

Herbert Spencer defined "life" as "the continuous adjustment of internal relations with external conditions." ${ }^{22}$ In architecture, it is the wall that performs this continual adjustment between the internal and the external. Problems of the wall are problems of what is properly inside and outside architecture and how it acts as a threshold between the two. To Schuyler and his contemporaries, the wall was a necessary barrier against the dangerous energies external to architecture caused by the growing mechanization and rationalization of modern life. Schuyler was ambivalent about the Reliance because he was not sure to what degree it resisted this threatening external environment or allowed its pervasive presence. If it is the function of architecture to keep back this invading environment, perhaps it was safest to claim that the terra-cotta building was not architecture at all, since it seemed to allow this hazardous new climate to infiltrate the very material of the wall itself.

"Giedion, Mendelsohn, Corbusier turned the abiding places of man into a transit area for every conceivable kind of energy and for waves of light and air," wrote Walter Benjamin. ${ }^{43}$ However, it was Benjamin who allowed for the presence of this disturbing psychic energy, the response to threats to the individual sense of being, that Giedion would not allow. For Giedion, it was safer to claim that a unified sense of the interior environment had been lost in modernity than to admit the presence of a fearful atmosphere of conflicting energies. In his polemical histories, Space, Time and Architecture and Mechanization Takes Command, he tried to eliminate this dangerous environment. In the first, he described an architectural structure ordering abstract space, which flows through and around it. In the second, he showed how machines act independently within this space. In this model, archi- 
tectural material exists only as structure and technological device. Its role as a space maker, in Semper's terms, is eliminated. Architecture is perceived as a boundariless body, a skeleton, and a series of disparate organs, rather than as a whole body with its own psychic interior realm. In this case, the wall must be conceived of as immaterial. To allow it mass would be to shroud perception of the structure, the unconscious of building, allowing for dark and hidden corners, spaces that could not be seen but only felt.

Whether made positively or negatively, the characterization of the curtain wall as functionally "immaterial," a pure image or sign, transparent to the activities within, equates it with a naive idea of the photograph as a pure simulacrum of reality. However, even if we accept the curtain wall as the point at which the medium of architecture meets the medium of photography, we need not assume that it operates purely as an index. From the very first image of its slender steel framing being erected, photographs of the Reliance were staged: they represented the building as a triumphant monument within a grand narrative of civic order. ${ }^{44}$ This effect did not occur simply by letting light fall directly on an exposed plate. It was created through the manipulation of complex photographic technologies. Just as the photograph cannot exist independently from constructions of meaning, the lightweight terra-cotta cladding of the Reliance Building should not be seen as an autonomous medium. It exists within a discourse of continually changing reception and criticism, and the mutable interpretations to which it is subject have the ability to alter our perception of its material presence.

Although the walls of the Reliance have been continually read through questions of surface and materiality and the relative relationship between skin and structure, these questions dodge the modernist understanding of the materiality of space itself as a physical and psychic entity. Assessing the various ways in which the Reliance has been understood reveals an unspoken fear in architectural modernism: that the architectural body might not be a pristine and immortal skeleton, but a living organism, prone to contamination and corruption. The readings of the wall, whether opaque or transparent, thick or thin, allowed architectural critics and historians to control, without naming, that which the wall repelled. The fog or miasma swirling around the building in its much-reproduced photographs may have been giving us the clue all along. The trace left behind is not only that of the smoke and smog of the nineteenth-century industrial city, but the thickness of an atmosphere fraught with conflicting energies: those that threatened to break down the barriers between bodies and machines and those that attempted to resist them. 


\section{Notes}

1. Joseph Rykwert, "Architecture is All on the Surface: Semper and Bekleidung," Rassegna 20, no. 73 (1998): 20-29.

2. For an outline of the various genealogies of the skyscraper, see Rosemarie Haag Bletter's "The Invention of the Skyscraper: Notes on Its Diverse Histories," Assemblage no. 2 (1987): 110-17.

3. The Reliance Building was named a National Historic Landmark in 1976. The recent renovation was undertaken by the McClier Corporation, with Antunovich Associates. See Todd Savage, "Burnham, Baby, Burnham,” Metropolis 18 (July 1999): 88-91; Thomas Connors, "Chicago's Historic Reliance Building to Be Refurbished as a Hotel," Architectural Record 187 (April 1999): 60; Howard S. Decker, "The Count on the Reliance Building," Inland Architect 37 (May-June 1993): 23-24; Elwin Robison, "Notes on the Reliance Building Restoration," Architronic: The Electronic Journal of Architecture 3, no. 2 (1994): 6; Alan Schachtman, "Renovating Chicago's Reliance Building," Urban Land 55 (February 1996): 13, 42, 44; and M. J. P. Smith, "Shoring Support for the Reliance," Inland Architect 32 (September-October 1988): $5,9$.

4. Larry A. Viskochil has described the circumstances surrounding the production of photographs like these in Chicago at the Turn of the Century in Photographs: 122 Historic Views from the Collections of the Chicago Historical Society (New York: Dover, 1984). Produced largely for advertising purposes, they were most often printed as picture postcards, which were legally allowed by the U.S. Postal Service for the first time in 1893. See also Peter Bacon Hales' Silver Cities: The Photography of American Urbanization, 1839-1915 (Philadelphia: Temple University Press, 1984).

5. Carl Condit, The Chicago School of Architecture: A History of Commercial and Public Buildings in the Chicago Area,
1875-1925 (Chicago: University of Chicago

Press, 1964), 110-11.

6. Sigfried Giedion, Space, Time and Architecture: The Growth of a New Tradition (1941; reprint, Cambridge: Harvard University Press, 1973), 385-88. The earlytwentieth-century "discovery" of modernism's origins in late-nineteenth-century Chicago architecture also forms the basis of Philip Johnson's Early Modern Architecture in Chicago, 1870-1910 (New York: Museum of Modern Art, 1940).

7. "Chicago," American Architect and Building News 47 (January 26, 1895): 43.

8. Engineering Magazine (London), no. 8 (October 1894-March 1895): 896. The building was originally designed by Burnham's first partner, John Wellborn Root. However, Root died just as the first stage of construction, the basement and ground floor, was being completed. Charles Atwood, Burnham's new partner, substantially revised the design of the upper stories. For a description of the complex process of design and construction of the Reliance Building, see Donald Hoffman, "The Reliance Building: A Metamorphosis," chap. 8 in The Architecture of John Wellborn Root (Chicago: University of Chicago Press, 1973).

9. Architect (December 8, 1894): 895.

10. Manfredo Tafuri and Francesco Dal Co, Modern Architecture (New York: Harry N. Abrams, 1977), 67. Carol Willis repeats this argument in Form Follows Finance: Skyscrapers and Skylines in New York and Chicago (New York: Princeton Architectural Press, 1995), which "shows how market formulas produced characteristic [skyscraper] forms in each city."

11. William Le Baron Jenney, "The Chicago Construction, or Tall Buildings on a Compressible Soil," Inland Architect and News Record 18 (November 1891): 41.

12. Montgomery Schuyler, "D. H. Burnham and Co.," no. 2, pt. 2, in the "Great American Architects Series" by Architectural Record (February 1896): 
49-69. Reprinted in William Jordy and Ralph Coe, eds., American Architecture and Other Writings (Cambridge: Harvard University Press, Belknap Press, 1961), 405-18. My italics.

13. My thanks to Mark Wigley for drawing this to my attention.

14. Schuyler, "D. H. Burnham and Co.," 405.

15. Robert Bruegmann, Holabird and Roche, Holabird and Root: An Illustrated Catalogue of Works, 1880-1940, 3 vols. (New York: Garland, 1991), 12.

16. Colin Rowe, The Mathematics of the Ideal Villa and Other Essays (Cambridge: MIT Press, 1990), 103.

17. "Chicago," 43.

18. Schuyler, "D. H. Burnham and Co.," 411.

19. George M. R. Twose, "The Use of Terra-Cotta in Modern Buildings," Engineering no. 8 (October 1894-March 1895): 203-19.

20. Twose, "The Use of Terra-Cotta in Modern Buildings,” 217.

21. Thomas Tallmadge, ed., 1939 introduction to The Origin of the Skyscraper (Chicago: Alderbrink, 1931), 4.

22. William H. Jordy, Progressive and Academic Ideals at the Turn of the Twentieth Century, vol. 4 of American Buildings and Their Architects (New York: Oxford University Press, 1972), 61.

23. Walter Gropius, The New Architecture and the Bauhaus, trans. P. Morton Shand (1965; reprint, Cambridge: MIT Press, 1996), 43.

24. Charles Jenkins, "A White Enameled Building," Architectural Record 4 (JanuaryMarch 1895): 299-306.

25. Joseph Kirkland's History of Chicago (1894); quoted in Bruegmann, Holabird and Roche, 143.

26. Henry Blake Fuller, The CliffDwellers (New York: Harper and Brothers, 1893), 1-4.

27. Lauren S. Weingarden has described attempts to naturalize the tall office building in "Naturalized Naturalism: A Ruskinian Discourse on the Search for an American Style of Architecture," Winterthur Portfolio 24, no. 1 (spring 1989): 43-68.

28. Fuller, The Cliff-Dwellers, 8.

29. Henry Van Brunt, "Architecture in the West” (1889), in William A. Coles, ed., Architecture and Society: Selected Essays of Henry Van Brunt (Cambridge: Harvard University Press, Belknap Press, 1969), 223.

30. Fuller, The Cliff-Dwellers, 8.

31. Even a quick examination of these plans, however, reveals an interesting inversion in the interior arrangement of the Reliance Building. As in many other office buildings of the time, each floor is made up of a number of similarly sized offices, grouped along a central corridor, elevator shaft, and stairwell. The offices are stacked two deep along the outer walls. The first in this pair is the "outer office," occupied by junior clerks. The "inner office," that facing out into the street, was occupied by more senior office staff. Looking at the plan, we can see that the inner core (the elevator shaft and corridor) are the most public areas of the building, and the inner offices, closest to the windows, are the most private. The hierarchy of space is reversed from that of a private house and almost every other building type. The floors above the ground floor are all treated as if they were well above the level of the surrounding city. Their planning assumes that their windows would not be overlooked, that they can act as lenses to the sky, admitting plentiful light but not the gaze of others. Conversely, looking out, one was assumed to have only a distant view of the city.

32. John Wellborn Root and Fritz Wagner translated a section of Gottfried Semper's Der Stil in den Technischen und Tektonischen Kunsten, 2 vols. (Munich, 1860-1863), as "Development of Architectural Style," parts 1-4, Inland Architect 14, no. 7 (December 1889): 76-78; no. 8 (January 1890): 92-94; 15, no. 1 (February 
1890): 5-6; and no. 2 (March 1890): 32-33. Root was probably introduced to Semper's writing by his friend, German-born Chicago architect Frederick Baumann, who wrote several articles explicating Semper's theory in the Inland Architect. These articles include "Thoughts on Architecture," 16 (November 1890): 59-60, and "Thoughts on Style," 20 (November 1892): 34-37. Baumann also translated an obituary of Semper, "To the Memory of Gottfried Semper," 20 (January 1893): 62-63.

33. John Wellborn Root, "The City House in the West" (1890) in Hoffman, The Architecture of John Wellborn Root, 223-33.

34. John Tyndall, Essays on the Floating Matter of the Air in Relation to Putrefaction and Infection (New York: D. Appleton, 1882).

35. "Chicago's Climate," Inland Architect and Builder 3 (May 1884): 51-52.

36. The Dial: A Monthly Review and Index of Current Literature (Chicago, 1880-1893).

37. Cited in Robert L. Cameiro, introduction to The Evolution of Society: Selections from Herbert Spencer's Principles of Sociology, by Herbert Spencer, ed. Robert L. Cameiro (Chicago: University of Chicago Press, 1967), xxxv.

38. These books included Dr. John $\mathrm{H}$. Packard, Sea-Air and Sea-Bathing (1880); Marc Cook, The Wilderness Cure (1881); George M. Beard, American Nervousness (1881); C. Nordoff, California for Health, Pleasure and Residence (1882); Dr. J. Leonard Corning, Brain Exhaustion (1884); T. M. Coan, California for the Sick and the Well (1888); Walter Lindley, M.D., California of the South: Its Physical Geography and Climate (1888); and E. Angerstein, M.D., and G. Eckler, Home Gymnastics for the Well and the Sick (1889).

39. Barr Ferree, Comparative Archi- tecture (New York: privately published, 1892), 7.

40. Barr Ferree, "Architecture and Environment," Inland Architect and News Record 16 (December 1890): 72-74. This article was reprinted from Popular Science Monthly.

41. John Ruskin, "The Storm Cloud of the Nineteenth Century" (1884), in E. T. Cook and Alexander Wedderburn, eds., The Works of John Ruskin, vol. 34 (London, 1908), 18-39. See also Eduardo Cadava, Emerson and the Climates of History (Stanford, Calif.: Stanford University Press, 1997), for his discussion on the role of climate and weather as a metaphor for historical and political concerns in the work of Ralph Waldo Emerson. These two strains of thought, the scientized environmentalism of Ferree and the spiritualism of Ruskin, were brought together by books such as theologian Henry Drummond's Natural Law in the Spiritual World (1885), which attempted to find a scientific basis for the unknowable fear attendant on the modern city, at a level beyond that of climate, within the atomic basis of all life.

42. Cameiro, xxxv.

43. Walter Benjamin, Gesammelte Schriften, vol. 8, 196-97; quoted in Hilde Heynen, Architecture and Modernity (Cambridge: MIT Press, 1999), 114.

44. In Silver Cities, Hales describes a period of "Grand Style Urban Photography," lasting from 1870 until around 1893 , in which the aim of the increasingly professionalized photographer was to redefine the American city as "a place not of chaos, darkness and danger, but of order, light and intelligibility," in which poverty, disease, and race conflict were banished and new buildings were celebrated as symbols of civilized urban life (120). 